\title{
PROBLEMATIKA GANGGUAN KECEMASAN PADA LANJUT USIA DI LINGKUNGAN SOSIAL
}

\author{
Hildawati \\ Dosen Fakultas Tarbiyah dan Ilmu Keguruan UIN Datokarama Palu \\ hidawati@iainpalu.ac.id
}

\section{Abstract}

This study aims to determine 1) the problems of anxiety disorders in the elderly, 2) the causes of anxiety disorders in the elderly and 3) how to prevent and overcome anxiety disorders in the elderly. This research uses qualitative research with descriptive analysis. Data collection techniques were carried out using observation, interviews, and documentation methods involving six informants. Based on the results of the study, it shows that 1. problematic anxiety disorder is a condition experienced by someone who experiences excessive worry about a problem or situation so that it affects emotional disturbances and uncomfortable physical and psychological conditions characterized by feelings of restlessness, palpitations, fear, difficulty concentrating, sleep disturbances to difficulty breathing / shortness of breath. The causes of anxiety disorders are extreme stress or trauma, complicated or chronic feelings of loss and grief, use of alcohol, caffeine, drugs (prescription, over-the-counter, and illegal), family history of anxiety disorders, neurodegenerative disorders (such as Alzheimer's or Alzheimer's disease). other dementias). 3. How to prevent anxiety disorders can be done by providing supportive conditions such as a living environment that ensures prosperity, allows a healthy and integrated lifestyle. Meanwhile, if the elderly experience anxiety disorders, treatment can be carried out, and also needs support from family or other social groups.

Keywords: anxiety disorder, Elderly

\section{Abstrak}

Penelitian ini bertujuan untuk mengetahui 1) problematika gangguan kecemasan pada lanjut usia, 2) penyebab gangguan kecemasan pada lanjut usia dan 3) Bagaimana cara mencegah dan mengatasi gangguan kecemasan pada lanjut usia. Penelitian ini menggunakan penelitian kualitatif dengan analisis deskriptif. Teknik pengumpulan data dilakukan dengan menggunakan metode observasi, wawancara, dan dokumentasi dengan melibatkan individu sebanyak enam orang informan. Berdasarkan hasil penelitian menunjukkan bahwa 1. problematika gangguan kecemasan adalah suatu kondisi yang dialami seseorang yang mengalami kekhawatiran berlebihan terhadap suatu masalah atau keadaan sehingga mempengaruhi gangguan emosi dan kondisi fisik 
dan psikis yang tidak nyaman ditandai dengan perasaan gelisah, jantung berdebar, takut, sulit berkonsentrasi, gangguan tidur hingga kesulitan bernapas/sesak. 2 . penyebab gangguan kecemasan adalah stres atau trauma ekstrem, rasa kehilangan dan kesedihan yang rumit atau kronis, penggunaan alkohol, kafein, obat-obatan (resep, tanpa resep, dan ilegal), riwayat gangguan kecemasan dalam keluarga, gangguan neurodegeneratif (seperti alzheimer atau demensia lainnya). 3. cara mencegah gangguan kecemasan dapat dilakukan dengan menyediakan kondisi yang mendukung seperti lingkungan hidup yang menjamin kesejahteraan, memungkinkan gaya hidup sehat dan terintegrasi. Sementara jika lansia mengalami gangguan kecemasan maka dapat dilakukan perawatan, dan juga membutuhkan dukungan dari keluarga atau sosial lainnya.

Kata kunci : gangguan kecemasan. lanjut usia

\section{Pendahuluan}

Manusia memulai siklus kehidupan dari lahir sebagai bayi, tumbuh dan berkembang hingga menjadi manula atau masuk masa lanjut usia. Lanjut usia atau disingkat lansia di Indonesia kian meningkat selama beberapa tahun. Kantor Kementrian Koordinator Kesejahteraan Rakyat (KESRA) melaporkan bahwa pada tahun 1980 5,54\% dari jumlah penduduk Indonesia termasuk dalam usia lansia, menjadi 8,90\% di tahun 2006, di tahun 2010 menjadi 9,77\% dan diperkirakan menyentuh angka 22,8 juta atau 11,34\% di tahun 2020. Makin meningkatnya jumlah lansia di Indonesia menjadi masalah penting karena membutuhkan penanganan yang serius ${ }^{1}$.

Masa lansia menjadi masa perkembangan yang dimulai pada tahun 60 -an atau 70 -an dan berlangsung sampai mati. Menjadi waktu untuk peninjauan hidup, pensiun, dan penyesuaian untuk peran sosial baru yang melibatkan penurunan kekuatan dan kesehatan. Penurunan kesehatan para lansia tidak hanya pada fisik tetapi juga gangguan kesehatan mental (Santrock, 2011). Lebih lanjut dijelaskan oleh Ajhuri (2019) bahwa penurunan intelektual lansia diakibatkan oleh berbagai faktor salah satunya ialah kecemasan. Penuaan degeneratif akan

${ }^{1}$ Kusumowardani, A., \& Puspitosari, A. (2014). Hubungan antara Tingkat Depresi Lansia Dengan Interaksi sosial Lansia di Desa Sobokerto Kecamatan Ngemplak Boyolali. Jurnal Terpadu Ilmu Kesebatan. Volume 3, No. 2, 184-188. 
berdampak pada perubahan fisik, kognitif, perasaan, sosial, dan seksual2. Perubahan pada kondisi fisik pada lansia biasanya ditandai dengan kulit yang keriput, rambut beruban,mudah sakit karena kekuatan fisik yang menurun biasanya karena penyakit yang dialami misalnya karena gangguan fungsi ginjal,gangguan fungsi jantung dan pembuluh darah, gangguan sistem saraf dan sistem pencernaan. Selain itu fungsi alat vitalpun semakin menurun, hal ini biasanya ditandai dengan penglihatan yang mulai kabur, gangguan pendengaran, sistem pernafasan dan gangguan lainnya.

Adapun perubahan yang terjadi pada non fisik biasanya terlihat pada kondisi perasaan atau emosi pada lansia. Tidak heran ketika kita melihat lansia yang pikun, smudah marah, mudah tersinggung, atau sering menangis bahkan cemas berlebihan terhadap suatu masalah yang sebenarnya masalah tersebut adalah hal yang biasa. Sebagai contoh ada seorang lansia yang meluapkan kemarahannya kepada tontonan video atau film yang berkarakter antagonis, dengan luapan makian dan cemohan yang terlontar seolah-olah orang itu ada di depannya padahal yang ditonton hanyalah sebuah film yang diperankan. Kasus lain ada lansia yang sangat cemas karena dianggap dia akan ditinggalkan oleh istri dan anak- anaknya saat dia tidak lagi memperoleh penghasilan atau memasuki usia pension.

Perubahan-perubahan ini tentu mempengaruhi perilaku, sikap dan pembawaaannya dalam kehidupan sehari-hari. Perilaku yang terjadi pada lansia ini tidak jarang membuat orang di sekitarnya cenderung kaget atau shock bahkan bingung karena ini adalah sesuatu yang baru dirasakan oleh mereka ketika berinteraksi dengan lansia di sekitarnya.

Dengan pemaparan data-data diatas, menjadi masalah yang penting bagi Indonesia, terutama masyarakat lansia dan juga para keluarganya. Maka peneliti tertarik melakukan penelitian tentang gangguan kecemasan pada lansia. Peneliti berharap dapat menjelaskan tentang gangguan kecemasan pada lansia, memberikan cara mencegah atau solusi atas gangguan kecemasan pada lansia agar dapat memberi kesadaran untuk masyarakat akan pentingnya menjaga kesehatan lansia terutama masalah kesehatan mental mengenai kecemasan.

\section{Metode Penelitian}

Jenis penelitian yang digunakan adalah deskriptif kualitatif yaitu suatu metode penelitian yang dilakukan dengan membuat gambaran atau deskripsi tentang suatu keadaan secara

\footnotetext{
2 Rindayanti, Nasir, A., \& Astriani, Y. (2020). Gambaran Kejadian dan Tingkat Kecemasan pada Lanjut Usia. Jurnal Kesehatan Vokasional. Volume 5, No. 2, Halaman 95-101.
} 
objektif. penelitian kualitatif bersifat studi kasus yang bertujuan untuk menggambarkan, meringkas berbagai kondisi, berbagai situasi atau berbagai fenomena realitas sosial yang ada dalam masyarakat yang menjadi objek penelitian yang berupaya menarik realitas itu ke permukaan sebagi suatu ciri, karekter, sifat, model tanda atau gambaran tentang kondisi, situasi atau fenomena tertentu. Penelitian kualitatif bertujuan untuk memahami realitas sosial, yaitu melihat subjek penelitian dari apa adanya, bukan dari apa yang seharusnya. ${ }^{8}$

Teknik pengumpulan data dalam penelitian ini dilakukan dengan metode sebagai berikut:

\section{Observasi}

Observasi atau pengamatan adalah metode pengumpulan data yang digunakan untuk menghimpun data penelitian melalui pengamatan dengan menggunakan pancaindra.

2. Wawancara

Wawancara adalah percakapan dengan maksud tertentu. Teknik wawancara yang digunakan dalam penelitian ini adalah wawancara berpedoman atau terikat, serta wawancara bebas dan mendalam (indept interview).

\section{Dokumentasi}

Dokumentasi ini digunakan untu memperuat data-data yang diperoleh dari metodeyang digunakan sebelumnya. Metode ini dilakukan untuk pengumpulan data sekunder yang sudah tertulis maupun melalui pengambilan gambar aktivitas dilokasi berupa arsip atau dokumen dan foto secara optimal yang memberikan penjelasan dan keterangan lengkap mengenai perihal yang diteliti.

\footnotetext{
7 Hendraswati, Dalle, J., dan Jamalie, Z. (2017). Diaspora dan Ketahanan Budaya Orang Bugis diPagatan
} Tanah Bumbu (PDF). Yogyakarta: Penerbit Kepel Press. 2-3. ISBN 978-602-356-197-1.

8 Bungin, Burhanuddin. 2008. Sosiologi Komunikasi. Jakarta: Prenada Media Group. 6 
Data hasil penelitian dari informan yang terkumpul baik hasil wawancara, observasi maupun dokumentasi selanjutnya dianalisis. Menurut Miles dan Huberman dalam Moleong (2002: 295) analisis data kualitatif terdiri atas; reduksi data, penyajian data dan penarikan kesimpulan/verifikasi. (1) Reduksi data yaitu, proses pemilihan, pemusatan perhatian pada penyederhanaan, pengabstrakan, dan transformasi data kasar yang muncul dari catatan tertulis dilapangan yang berhubungan dengan permasalahan penelitian. (2) Penyajian data, yaitu sekumpulan data informasi tersusun yang member kemungkinan adanya penakrikan kesimpulan dan pengambilan tindakan secara logis dan sistematis sesuai dengan teori yang ada hubungannya dengan permasalahan penelitian. (3) Melalui penyajian data tersebut maka data tergonisir, tersususun dalam pola hubungan sehingga dapat menarik kesimpulan/verifikasi.

\section{Hasil Penelitian}

\section{Pengertian Gangguan Kecemasan}

Menurut Trismiati (dalam Annisa dan Ifdil, 2016), anxiety (kecemasan), asalnya dari kata Latin angustus yang berarti kaku, dan ango, anci yang artinya mencekik. Sementara Schwartz (dalam Annisa dan Ifdil, 2016) mengatakan bahwa kecemasan berasal dari Bahasa Latin anxius yang berarti constriction (kesesakan) atau strangulation (pencekikan). ${ }^{3}$ Kecemasan menurut Dariah dan Okatiranti (2015), adalah rasa khawatir yang membingungkan dan menyebar yang menyangkut emosi yang tidak jelas dan tidak berdaya. Kondisi emosi ini tidak mempunyai objek yang bersifat khusus. Kecemasan pengalaman subjektif dan dikomunikasikan secara interpersonal (Stuart dalam Dariah dan Okatiranti, 2015) ${ }^{4}$ Kecemasan serupa dengan ketakukan, tapi dengan fokus yang kurang jelas. Rasa takut biasanya berupa reaksi terhadap ancaman langsung, namun kecemasan ditandai dengan ketakutan akan bahaya yang tidak terduga di masa depan. Kecemasan adalah kondisi emosi negatif yang dikenali dengan firasat dan tanda ketegangan fisik, seperti denyut jantung yang cepat, berkeringat, dan kesulitan bernapas.

Seseorang dapat dikatakan memiliki gangguan kecemasan bila kekhawatirannya tidak wajar dan menunjukkan reaksi fisik seperti jantung berdebar-debar, keringat dingin,

3 Annisa, D., F., \& Ifdil. (2016). Konsep Kecemasan (Anxiety) pada Lanjut Usia (Lansia). Konselor, Volume 5, 93-99.

${ }^{4}$ Dariah, D., D., Okatiranti. (2015). Hubungan Kecemasan dengan Kualitas Tidur Lansia di POSBINDU Anyelir Kecamatan Cisarua Kabupaten Bandung Barat. Jurnal Ilmu Keperawatan. Volume III, No.2, 87-104. 
tekanan darah meningkat, sakit kepala, atau reaksi psikis seperti sulit berkonsentrasi, gelisah, gangguan tidur, dan reaksi emosional yang kuat. Kecemasan yang terus-menerus berlangsung, dapat menyebabkan kelelahan mental, depresi dan kemungkinan berkembangnya gangguan jiwa yang lain. ${ }^{5}$

Dari berbagai pendapat di atas dapat disimpulkan bahwa gangguan kecemasan adalah suatu kondisi yang dialami seseorang yang mengalami kekhawatiran berlebihan terhadap suatu masalah atau keadaan sehingga mempengaruhi gangguan emosi dan kondisi fisik dan psikis yang tidak nyaman ditandai dengan perasaan gelisah, jantung berdebar, takut, sulit berkonsentrasi, gangguan tidur hingga kesulitan bernapas/sesak

\section{Penyebab Gangguan Kecemasan Pada Lanjut Usia}

Menurut Diferiansyah, dkk. (2016), orang yang mengalami gangguan kecemasan mungkin menunjukkan perilaku abnormal, seperti panik tanpa alasan, ketakutan yang tidak masuk akal terhadap objek atau kondisi kehidupan, melakukan tindakan berulang yang kembali mengalami peristiwa yang traumatis atau rasa khawatir yang tidak bisa dijelaskan atau berlebihan. Ada beberapa studi empiris yang merincikan gangguan kecemasan di usia lanjut. Tetapi, data terbaru menyoroti gangguan kecemasan umum (generalized anxiety disorder), gangguan panik (panic disorder), fobia spesifik (Specific Phobias), dan gangguan stres pasca trauma (Post-Traumatic Stress Disorder) di usia lanjut ${ }^{6}$.

Sejumlah hal dapat menyebabkan pada gangguan kecemasan seperti (Geriatric Mental Health Foundation, n.d.):

1. Stres atau trauma ekstrem

2. Rasa kehilangan dan kesedihan yang rumit atau kronis

3. Alkohol, kafein, obat-obatan (resep, tanpa resep, dan ilegal)

4. Riwayat gangguan kecemasan dalam keluarga

5. Gangguan neurodegeneratif (seperti alzheimer atau demensia lainnya)

Menurut Geriatric Mental Health Foundation (n.d.), stres dan perubahan seiring dengan penuaan seperti kesehatan yang memburuk, masalah memori, dan kehilangan dapat menyebabkan gangguan kecemasan. ${ }^{7}$ Ketakutan umum tentang

\footnotetext{
${ }_{5}^{5}$ Nida, F., L., K. (2014). Zikir Sebagai Psikoterapi Dalam Gangguan Kecemasan Bagi Lansia. KONSELING RELIGI: Jurnal Bimbingan Konseling Islam. Volume 5, No. 1, 133-150.

${ }^{6}$ Lauderdale, S., \& Sheikh, J. (2003). Anxiety disorders in older adults. Clinics in geriatric medicine. 19. 721-41. 10.1016/S0749-0690(03)00047-8.

7 Geriatric Mental Health Foundation. (n.d.) Anxiety and Older Adults: Overcoming Worry and Fear. 10 November 2021. https://www.aagponline.org/.
} 
penuaan dapat menyebabkan kecemasan. Banyak lansia takut jatuh, tidak mampu membayar biaya hidup dan pengobatan, menjadi korban, bergantung pada orang lain, ditinggalkan sendirian, dan kematian. Lansia dan keluarganya harus menyadari bahwa perubahan kesehatan juga dapat menyebabkan kecemasan. Gangguan kecemasan umunya terjadi bersamaan dengan penyakit fisik atau mental lainnya, termasuk penyalahgunaan alkohol atau zat yang dapat menyembunyikan gejala atau memperburuknya.

Kondisi-kondisi lansia di atas menjadi pemicu munculnya gangguan penyakit fisik yang lain, misalnya jika seorang lansia terlalu khawatir dan merasa sangat sedih karena kehilangan atau ditinggalkan oleh orang yang dicintainya sehingga dia kehilangan selera makannya maka diapun terserang penyakit maag yang menyebabkan kondisi fisiknya semakin lemah

Selain itu, ada juga kondisi lansia yang merasa sangat stress karena telah mendekati masa pensiun dan merasa sangat pesimis menjalani hidupnya ke depan dengan kondisi finansial yang sudah berbeda, sehingga kekhawatiran ini berdampak pada rasa cemas dan merasa nanti dia tidak punya apa-apa dan tidak bisa lagi menjalani kehidupannya yang normal seperti sebelumnya.

Ada juga kondisi lansia dengan kecemasan karena sakit-sakitan di masa tuanya. Dia seolah tidak bisa menerima kondisinya yang sakit karena sebelumnya dia merasa sehat, bugar bisa ke mana saja dan bisa melakukan apa saja. Sehingga ketika dirinya terserang penyakit dia sangat pesimis,takut, cemas dan mengaggap dirinya tidak mampu melakukan apa-apa dan merasa tidak berguna lagi.

Penting juga untuk diperhatikan bahwa banyak lansia yang hidup dengan kecemasan mengalami gangguan kecemasan (mungkin tidak terdiagnosis dan tidak diobati) ketika mereka masih muda. Peristiwa yang membuat stres, seperti kematian orang yang dicintai, dapat menyebabkan kecemasan ringan dan singkat, tetapi kecemasan yang berlangsung setidaknya enam bulan dapat menjadi lebih buruk jika tidak ditangani ${ }^{8}$

Olehnya itu, ketika melihat lansia mengalami peristiwa seperti yang telah dijelaskan di atas, sebaiknya keluarga atau orang terdekatnya memberikan alternatif solusi misalnya dengan memotivasi, merawat dan memahami kondisi lansia tersebut 
Moderasi Jurnal Studi Ilmu Pengetahuan Sosial, Volume 2, No. 2, h. 1-7

4

atau memeriksakan kepada ahlinya (psikiater/ dokter jiwa) untuk mengatasi gannguan kecemasan yang dialaminya

\section{Cara Mencegah atau Mengatasi Gangguan Kecemasan Pada Lanjut usia}

Lansia yang mungkin menderita gangguan kecemasan harus menyampaikan kekhawatirannya dengan dokter atau perawat mereka. Seorang dokter dapat membantu menentukan apakah gejala-gejala yang dialami disebabkan oleh gangguan kecemasan, kondisi medis, atau keduanya. Jika dokter mendiagnosis gangguan kecemasan, langkah selanjunya adalah menemui ahli perawatan kesehatan mental. Keduanya harus bekerja sebagai tim untuk membuat rencana untuk mengobati gangguan kecemasan?

Dukungan keluarga sangat dibutuhkan pada lansia yang mengalami keadaan seperti ini. Mereka juga harus memahamkan orang di sekitarnya agar mereka tidak terganggu dalam perilaku sosial karena ganggauan yang dialami oleh lansia

Geriatric Mental Health Foundation (n.d.) mengatakan bahwa perawatan dapat melibatkan pengobatan, terapi, pengurangan stres, coping skill, dan dukungan keluarga atau sosial lainnya. Penyedia perawatan kesehatan mental dapat menentukan jenis gangguan atau kombinasi gangguan yang dialami pasien, dan jika ada kondisi lain, seperti kesedihan, depresi, penyalahgunaan zat, atau demensia. Mereka yang telah dirawat sebelumnya karena gangguan kecemasan harus memberi tahu penyedia mereka tentang perawatan sebelumnya. Jika mereka menerima pengobatan, mereka harus menunjukkan apa yang digunakan, dosis, efek samping, dan apakah pengobatan itu membantu. Jika pasien menghadiri sesi terapi, dia harus menjelaskan jenisnya, berapa sesi, dan apakah itu membantu. Kadang-kadang individu harus mencoba beberapa perawatan atau kombinasi perawatan yang berbeda sebelum mereka menemukan perawatan yang paling cocok untuk mereka.

Menurut Nowshin dan Kabir (2014) dukungan kesehatan mental untuk lansia melibatkan penciptaan kondisi dan lingkungan hidup yang mendukung kesejahteraan dan memungkinkan orang untuk menjalani gaya hidup sehat dan terintegrasi, seperti memberikan keamanan dan kebebasan, perumahan yang layak melalui kebijakan perumahan yang mendukung, dukungan sosial untuk populasi lansia dan pengasuh

\footnotetext{
${ }^{9}$ ibid
} 
Moderasi Jurnal Studi Ilmu Pengetahuan Sosial, Volume 2, No. 2, h. 1-7

mereka, program pencegahan kekerasan dan penganiayaan lansia, dan program pengembangan masyarakat. ${ }^{10}$

Salah satu solusi yang bisa ditawarkan pada lansia yang mengalami gangguan kecemasan adalah dengan mengajak berbicara tentang apa yang dia rasakan,mulai dari kondisi fisik (penyakit atau rasa sakit fisik yang dikeluhkan) membiarkan dia bercerita apa saja tentang pengalaman hidupnya di masa lalu. Hal ini mungkin menjadikan orang bosan bagi yang mendengar karena cerita seperti ini biasanya sudah berulang kali diceritakan oleh lansia tetapi mendengarkan dia bercerita adalah salah satu hiburan tersendiri bagi lansia. Pendengar bisa menyisipkan kalimat motivasi atau pujian yang bisa membangkitkan semangat hidupnya. ${ }^{11}$

Ada juga lansia yang mengatasi kecemasannya dengan mengikuti majelis ilmu, misalnya majelis ta'lim, tabligh akbar kegiatan sosial, atau pengajian rutin bulanan yang dilakukan oleh warga sekitar sehingga dengan kegiatan ini lansia merasa bahwa sisa umurnya lebih baik dia habiskan pada kegiatan positif seperti ini dan berharap bisa meninggal dalam keadaan husnul khatimah melalui bekal keimanan yang $\operatorname{dimiliki}^{12}$

Di lain tempat, ada lansia yang mengatasi kecemasannya dengan menonton video yang dianggap menghibur dan bermanfaat buat dirinya. Lansia ini biasanya Banyak menghabiskan waktunya dengan menonton video lucu, film pendek yang memotivasi hidup atau ceramah- ceramah keagamaan yang dibawakan oleh ustadz/ ustadzah. Tontonan seperti ini membuat lansia merasa lebih semangat menjalani hidupnya dan perlahan bisa mengatasi gangguan kecemasannya karena merasa hidup itu tidak selamanya mudah, hidup itu pasang surut, kadang sakit kadang sehat, kadang sedih kadang bahagia sehingga dia tidak perlu terlalu pusing menjalani kehidupannya. Cukup dengan menerima apa yang terjadi pada dirinya dan membiarkan dia menjalani hidupnya dengan rasa tawakkal, penuh syukur dan ikhlas menjalani ketetapan yang telah ditakdirkan Allah kepada dirinya. ${ }^{13}$

Berbagai cara di atas adalah upaya lansia untuk bisa melanjutkan kehidupannya tanpa rasa cemas dan kekhawatiran yang berlebihan. Upaya-upaya ini tentu tidak bisa berjalan maksimal tanpa dukungan dari orang di sekitarnya. Olehnya itu, bantuan dan

\footnotetext{
${ }^{10}$ Nowshin, I., \& Kabir, F. (2014). The silent geriatric giant- anxiety disorders in late life. Bangladesh Journal of Physiology and Pharmacology. 29. 10.3329/bjpp.v29i1-2.20065.

11 observasi

12 wawancara

13 Observasi dan wawancara
} 
dukungan baik secara materi dan non materi sangatlah dibutuhkan oleh para lansia. Apalagi jika lansia itu adalah orang tua kita maka tentu sebagai anak sangat dituntut untuk berbakti kepada kedua orang tua kita, sebagaimana perintah Allah dalam Alqur'an surah Al- Isra: 23-24 yang artinya "Dan Tuhanmu telah memerintahkan supaya kamu jangan menyembah selain Dia dan hendaklah kamu berbuat baik pada ibu bapakmu dengan sebaik-baiknya. Jika salah seorang di antara keduanya atau kedua-duanya sampai berumur lanjut dalam pemeliharaanmu, maka sekali-kali janganlah kamu mengatakan kepada keduanya perkataan "ah" dan janganlah kamu membentak mereka dan ucapkanlah kepada mereka perkataan yang mulia."

Ayat ini mengingatkan kepada kita bahwa orang tua yang telah memasuki usia lanjut atau lansia perlu dirawat, dipelihara, dipenuhi kebutuhannya dengan penuh kelembutan dan kasih sayang sebagaimana mereka telah merawat dan memelihara kita sejak kecil. Sebagai anak seharusnya tidak berbicara kasar atau bahkan membentak mereka karena kondisinya yang sudah semakin lemah dan renta tentu membutuhkan perhatian yang ekstra dari anak-anaknya

Dengan menjalani kewajiban sebagai anak maka lansia merasa hidupnya tidak sia-sia, dirinya masih dianggap dan dibutuhkan oleh anak-anaknya. Perasaannyapun tentu lebih bahagia dan bersemangat dalam menjalani hidup sehingga dia mampu menjalani kehidupannya dengan normal baik di lingkungan keluarganya maupun di lingkungan sosial lainnya.

\section{Kesimpulan}

Berdasarkan data dan teori di atas, semakin meningkatnya jumlah lansia di Indonesia menjadi masalah serius. Lansia memasuki masa perkembangan manusia yang seharusnya menjadi waktu untuk beristirahat dan menikmati usia tua namun terlihat bahwa lansia mengalami penurunan kesehatan tidak terkecuali kesehatan mental khususnya gangguan kecemasan. Cara mencegah gangguan kecemasan dapat dilakukan dengan menyediakan kondisi yang mendukung seperti lingkungan hidup yang menjamin kesejahteraan, memungkinkan gaya hidup sehat dan terintegrasi. Sementara jika lansia mengalami gangguan kecemasan maka dapat dilakukan perawatan, dan juga membutuhkan dukungan dari keluarga atau sosial lainnya. 


\section{Referensi}

Al-Qur'an Al-Karim Mushaf Al-Qur'an Tajwid, QS. Al-Mujadalah (58): 11, Cetakan : 10,9,8,7,6,5.4. Bandung: CV Penerbit Diponegoro, 2014.

Ajhuri, K., F. (2019). Psikologi Perkembangan Pendekatan Sepanjang Rentang Kehidupan. Yogyakarta: Penebar Media Pustaka.

Annisa, D., F., \& Ifdil. (2016). Konsep Kecemasan (Anxiety) pada Lanjut Usia (Lansia). Konselor, Volume 5, Halaman 93-99.

Dariah, D., D., Okatiranti. (2015). Hubungan Kecemasan dengan Kualitas Tidur Lansia di Posbindu Anyelir Kecamatan Cisarua Kabupaten Bandung Barat. Jurnal Ilmu Keperawatan. Volume III, No.2, Halaman 87-104.

Diferiansyah, O., Septa, T., \& Lisiswanti, R. (2016). Gangguan Cemas Menyeluruh. J Medula Unila. Volume 5, Halaman 63-68.

Geriatric Mental Health Foundation. (n.d.) Anxiety and Older Adults: Overcoming Worry and Fear. 16 November 2020. https://www.aagponline.org/.

Kusumowardani, A., \& Puspitosari, A. (2014). Hubungan antara Tingkat Depresi Lansia Dengan Interaksi sosial Lansia di Desa Sobokerto Kecamatan Ngemplak Boyolali. Jurnal Terpadu Ilmu Kesehatan. Volume 3, No. 2, Halaman 184-188.

Lauderdale, S., \& Sheikh, J. (2003). Anxiety disorders in older adults. Clinics in geriatric medicine. 19. 721-41. 10.1016/S0749-0690(03)00047-8.

Nida, F., L., K. (2014). Zikir Sebagai Psikoterapi Dalam Gangguan Kecemasan Bagi Lansia. KONSELING RELIGI: Jurnal Bimbingan Konseling Islam. Volume 5, No. 1, Halaman 133-150.

Nowshin, I., \& Kabir, F. (2014). The silent geriatric giant- anxiety disorders in late life. Bangladesh Journal of Physiology and Pharmacology. 29. 10.3329/bjpp.v29i12.20065 .

Rindayanti, Nasir, A., \& Astriani, Y. (2020). Gambaran Kejadian dan Tingkat Kecemasan pada Lanjut Usia. Jurnal Kesehatan Vokasional. Volume 5, No. 2, Halaman 95-101.

Santrock, J., W. (2011). Life-span Development Thirteen Edition. New York: McGrawHill.

Sugiyono .2010. Metode Penelitian Pendidikan; Pendekatan kualitati kuantitatif dan R\&D.Bandung: Alfabeta. 